\title{
Elméleti utcahálózatok forgalomlebonyolító képességének vizsgálata makroszkopikus modellezési eljárással II. - Eredmények
}

\section{Háznagy Andor Gellért ${ }^{1}$, Fi István²}

\author{
${ }^{1}$ Budapesti Közlekedési Központ \\ ${ }^{2}$ Budapesti Műszaki és Gazdaságtudományi Egyetem, Út és Vasútépítési \\ Tanszék \\ E-mail: andor.haznagy@bkk.hu, fi.istvan@epito.bme.hu
}

DOI: $10.36246 /$ UL.2020.1.02

\section{KIVONAT}

Településrészek utcahálózatának felépítése és a rajta hálózati szinten megjelenő forgalom lefolyása közötti kapcsolat elemzésével megállapítható, hogy az összetett utcahálózatok felépítése milyen hatással van a rajta megjelenő forgalom minőségére és lefolyására. A több részes cikksorozatban bemutatásra került kutatás négyzetrács alapú elméleti utcahálózatok forgalmi vizsgálatával arra kereste a választ, hogy az utcahálózatokat felépítő építőelemek, a közúti csomópontok és utcaszakaszok eltérő elhelyezkedése és kialakítása, mint paraméter, milyen hatással van a közúti hálózaton megjelenő forgalom lebonyolódására. A kutatás során az utcahálózatok felépítését tekintve 8 eltérő utcahálózati paraméterrel 23 utcahálózati modell került megvizsgálásra. A vizsgálatokat változó nagyságú forgalmi ráterheléssel, makroszkopikus környezetben, 8 forgalomminőséget jellemző paraméter alapján végeztem el. Az eredmények alapján, amelyet a cikksorozat második része tartalmaz, megállapítható, hogy a belső utcahálózatok kialakítása és kapacitása kisebb mértékben, míg a külső közúti infrastruktúrához kapcsolódó utcaszakaszok és csomópontok száma, elhelyezkedése és forgalmi kapacitása erősebben befolyásolja a forgalom lefolyását a 8 vizsgált forgalomminőséget jellemző paraméter alapján.

Kulcsszavak: települési utcahálózat, négyzetrácsos utcahálózat, hálózatelemzés, makroszkópikus forgalmi modell, forgalomminőség

\section{ABSTRACT}

One of the most important challenges in urban design is planning an appropriate street network, satisfying the demand of users with different transport modes. Understanding the nature of road networks has been thoroughly studied problem for many years and extensive professional literature is now available in this respect. Junctions and streets are the main parts of street network. Their effects to everyday traffic could be analysed with grid street network in the neighbourhood aspect. For this reason, I analysed in more articles, 8 different street network elements were analysed with 23 theoretical grid street network model, and macroscopic traffic modelling approach was used in this work. The outcomes were analysed with 8 different traffic quality characteristic measures. The second article of series contains the results of the research project. The outcomes showed, the connection types of street networks to outer road network were much more important than inner layout of street networks in the aspect of traffic flow. Furthermore, some similarities were found in terms of street network elements behaviour in this paper.

Keywords: urban street network layout, Grid street plan, Network analysis, Traffic modelling, Traffic quality 


\begin{abstract}
Háznagy Andor Gellért
Okl. épitömérnök, a Budapesti Müszaki és Gazdaságtudományi Egyetem Út és Vasútépítési Tanszékén szerezte MSc diplomáját 2014-ben. Ezt követöen 4 évig a Tanszék PhD hallgatója, jelenleg a Budapesti Közlekedési Központ munkatársa.
\end{abstract}

\title{
Dr. habil Fi István
}

Professor emeritus, MTA doktora (müszaki tudomány) Szakmai tevékenység: 3 könyv, 2 könyvfejezet, 6 egyetemi jegyzet, mintegy 150 tudományos publikáció és jelentés, jelentös számú terv, illetve megvalósult létesítmény. Speciális szakterület: forgalmi folyamatok lefolyása, intelligens forgalomszabályozás elmélete és gyakorlata, útpályaszerkezetek deformációja és méretezése.

\section{BeVEzetÉs}

A cikksorozat első részében bemutattam a kutatás során alkalmazott vizsgálati módszertant. Külön kitértem a területi és forgalmi modell felépítésére. Részletesen ismertettem a vizsgálat során elemzett 23 elméleti, négyzetrács alapú utcahálózati modellt, a 8 vizsgálati paramétert és az eredmények kiértékelését szolgáló 8 forgalomminőséget jellemző változót (Háznagy \& Fi 2019).

A cikksorozat második része a kutatás eredményeit és azok kiértékelési módszertantát tartalmazza a vizsgálatból származó következtetések levonásával.

\section{EREDMÉNYEK ÉS KÖVETKEZTETÉSEK}

\subsection{KUTATÁS SORÁN ELEMZETT FORGALOMMINÖSÉGET JELLEMZÖ MENNYISÉGEK}

A kutatás során az egyes vizsgálati paraméterek és a hálózatot felépítő építőelemek forgalomra gyakorolt hatásának kimutatása érdekében, összesen 8 forgalom minőséget jellemző mennyiség került elemzésre. E jellemzők KPI-ok (Key Performance Indicator - fö teljesítménymutató), olyan indikátorok, amelyek alapján egy adott területre vonatkozó beavatkozások hatása meghatározható (Parmenter, 2015) (PIARC, 2019). Mindegyik vizsgálathoz egyedi célt rendeltem, amelyek az alábbiak.

(i) Átlagos utazási idö alakulása forgalomnagyság függvényében

A megvizsgált utcahálózatokon megjelenő közúti forgalom átlagos utazási idő-forgalomnagyság összefüggésének elemzési célja az volt, hogy az utcahálózatokon 1 órás időintervallum alatt megjelenő, változó nagyságú forgalmi terhelés függvényében megállapítható legyen a hálózaton megjelenő forgalom és átlagos utazási idő kapcsolata.

(ii) Átlagos sebesség alakulása a forgalomnagyság függvényében

A megvizsgált utcahálózatokon megjelenő közúti forgalom átlagos sebesség-forgalomnagyság összefüggésének elemzési célja az volt, hogy az utcahálózatokon 1 órás időintervallum alatt megjelenő, változó nagyságú forgalmi terhelés függvényében megállapítható legyen a hálózaton megjelenő forgalom és átlagos sebesség kapcsolata.

(iii) Használt utcahálózat aránya a teljes utcahálózathoz viszonyitva a forgalomnagyság függvényében

A megvizsgált utcahálózatokon megjelenő közúti forgalom által használt utcahálózat aránya és a rendelkezésre álló teljes utcahálózathoz viszonyított aránya elemzésének célja az volt, hogy az utcahálózatokon 1 órás időintervallum alatt megjelenő, változó nagyságú forgalmi terhelés függvényében megállapítható legyen a közúti forgalom által használt utcaszakaszok aránya a teljes utcahálózathoz viszonyítva. 
(iv, v) Használt utcaszakaszokon kialakuló torlódás hossza, és torlódott és a használt utcaszakaszok aránya a forgalomnagyság függvényében

A megvizsgált utcahálózatokon megjelenő közúti forgalom által használt utcaszakaszokon kialakuló torlódások hosszának és a használt utcaszakaszok arányának elemzési célja az volt, hogy az utcahálózatokon 1 órás időintervallum alatt megjelenő, változó nagyságú forgalmi terhelés függvényében megállapítható legyen az utcaszakaszokon kialakuló torlódások hossza és a torlódás során érintett utcaszakaszok egymáshoz viszonyított aránya. Az eredmények kiértékelése során az utcahálózatokon kialakuló torlódások hosszát, és a torlódás során érintett utcaszakaszok arányát a használt utcaszakaszhoz viszonyítva került elemzésre.

(vi) Használt utcaszakaszok kapacitáskihasználtsága a forgalomnagyság függvényében

A megvizsgált utcahálózatokon megjelenő közúti forgalom által használt utcaszakaszok kapacitáskihasználtság-forgalomnagyság összefüggésének elemzési célja az volt, hogy az utcahálózatokon 1 órás időintervallum alatt megjelenő, változó nagyságú forgalmi terhelés függvényében megállapítható legyen az utcahálózatokon közlekedő járművek által érintett utcaszakaszok közúti forgalmi kapacitásának kihasználtsága.

(vii) Fajlagos utazási idő alakulása az átlagos sebesség függvényében

A megvizsgált utcahálózatokon megjelenő közúti forgalom fajlagos utazási idő-átlagos sebesség összefüggésének elemzési célja az volt, hogy az utcahálózatokon 1 órás időintervallum alatt megjelenő, változó nagyságú forgalmi terhelés függvényében megállapítható legyen, hogy az utcahálózatokon megjelenő közúti forgalom milyen hatással van a fajlagos utazási idő alakulására. A fajlagos utazási idő megadja az egységnyi út megtételéhez szükséges idő mennyiségét (Koller, 1986).

(viii) Átlagos csomóponti áthaladási időveszteség alakulása kijárati csomópontok esetében

A megvizsgált utcahálózatokon megjelenő közúti forgalom átlagos csomóponti áthaladási időveszteségének alakulása kijárati csomópontok esetében az elemzés célja az volt, hogy az utcahálózatokon 1 órás időintervallum alatt megjelenő, változó nagyságú forgalmi terhelés függvényében megállapítható legyen, hogy az utcahálózatokon megjelenő közúti forgalom milyen hatást gyakorol a kijárati csomópontok áthaladási időveszteségére. A kijárati csomópontok körforgalomként kerültek definiálásra.

\subsection{EREDMÉNYEK KIÉRTÉKELÉSÉNEK METÓDUSA}

A forgalmi ráterhelések elvégzését követően rendelkezésre állt minden belső és külső forgalmi zóna közötti útvonal, az útvonalakat bejárt jármüvek száma és az útvonalakhoz tartozó forgalmi jellemzök. A forgalmi jellemzőket (úm. sebesség, utazási idő, kapacitáskihasználtság, torlódás, csomóponti áthaladási időveszteség és a járművek által bejárt utcaszakaszok) a bejárt átvonalakhoz tartozó előfordulásuk gyakorisága alapján súlyozott átlaggal került megállapításra. Az eredmények kiértékelése során a függvényillesztéshez az Origin Pro programot használtam.

Az átlagos utazási idő és a forgalomnagyság, valamint az átlagos sebesség és forgalomnagyság összefüggések lefolyását tekintve a vizsgált utcahálózati modellek két csoportba bonthatók.

Az első csoportba tartoznak azok a vizsgált esetek, amelyeknél a forgalom kritikus értékü ráterhelése mellett, a telítetlen forgalmi állapotból túltelített lesz, a forgalom kismértékü növelésekor az átlagos sebesség hirtelen csökken, illetve az átlagos utazási idő hirtelen növekszik. Ez megfigyelhető, amikor a kijárati csomópontokhoz tartozó kijárati utakon, azaz a kijárati csomóponti ágakon megjelenő forgalom ezen utak forgalmi kapacitását meghaladja, a hálózatot elhagyó forgalom feltorlódik a kijárati csomóponti ágak előtt, az utcahálózat belsejében. A kijárati csomóponti ágak összegzett forgalmi kapacitásának hatását mutatja az is, hogy azon forgalomnagyságok mellett, amelyeknél a teljes közúti hálózat forgalmi áteresztő képessége jelentősen csökken, a kijárati csomópontok szolgáltatási szintje áganként 'B vagy ' $C$ ' szolgáltatási szint körül adódik. Ekkor nem a kijárati csomópontok, vagy a vizsgált 
területen belüli utcahálózat következtében jelentkezik hirtelen változás a forgalmi teljesítőképességben, hanem a kijárati csomóponti ágak összegzett forgalmi kapacitása függvényében. Ez megfigyelhető a III. és V. csoportba tartozó modellek esetén. A forgalmi határérték $\left(F_{h}\right)$ nagysága az utcahálózatok azon elemeinek összesített forgalmi kapacitásának környékén adódik, amelyek összesített kapacitása a forgalom lefolyása során először alacsonyabb, mint a hálózaton megjelenő teljes forgalom nagysága, azaz értékét a kritikus elhelyezkedésủ legszűkebb keresztmetszetű hálózati elemek forgalmi kapacitása adja meg.

A második csoportba tartozó többi esetben a határérték nem látható ilyen erőteljesen, az az átlagos sebesség-forgalomnagyság és átlagos utazási idö-forgalomnagyság esetében az eredményekre illeszthető folytonos függvény inflexiós pontja körül jelentkezik, amely összefügg a vizsgálat során alkalmazott ellenállásfüggvényekkel. $\mathrm{F}_{\mathrm{h}}$ a telítetlen és a túltelített állapot határán található és e forgalomnagyság környezetében kezd a vizsgált utcahálózatokon a torlódás kialakulni, lásd 4. ábra. A kijárati csomópontok szolgáltatási szintjeinek elemzése során minden vizsgált kialakítás esetében a határértékhez tartozó forgalomnagyságnál a kijárati csomópont szolgáltatási szintje (a csomóponti ágak szolgáltatási szintjeinek átlagaként) eléri az 'E' szolgáltatási szintet. Ebben az esetben a jármüvek csomóponti áthaladási idővesztesége 35 s és 50 s közötti értéket vesz fel, és ez az I., II., IV., VI. csoport esetében jelentkezik.

Az átlagos utazási idö-forgalomnagyság és átlagos sebesség-forgalomnagyság összefüggések esetén az eredményekre függvényt illesztettem a forgalmi határértéket megelőző és az azt követő esetekre. A forgalmi határérték mellett a függvényillesztésre hatással volt az utcaszakaszok telített és túltelített eseteinek kapcsolata (Akcelik, 2003) és a HCM metódusban megjelenő E szolgáltatási szint fontossága (Transportation Research Board National Research Council, 2010).

A függvényillesztés során az eredményeket minden esetben két részre osztottam. Első csoportba a minimális vizsgált forgalomnagyság $\left(F_{\min }\right)$ és a forgalmi határérték forgalomnagysága $\left(F_{h}\right)$ közötti forgalomnagyságok $(F)$ tartoznak, második csoportba a forgalmi határérték forgalomnagysága $\left(F_{h}\right)$ és a maximális vizsgált forgalomnagyság $\left(F_{m a x}\right)$ közötti értékek kerültek. Mindkét esetben az eredményekre exponenciális függvényt illesztettem, amelyek 0,95-nél magasabb regressziós értékkel rendelkeznek. Az alkalmazott exponenciális függvény a következő volt.

$\mathrm{y}=y_{0}+A e^{\left(R_{0} x\right)}$

A függvényillesztéseket a 1. ábra és 2. ábra tartalmazza. Az ábrákon az első csoportba tartozó illesztéseket szaggatott vonal, míg a második csoportba tartozó illesztéseket pontozott vonal jelöli. A grafikonokon az első csoportba tartozó forgalmi ráterheléseket kitöltött pontok $\left(F_{\min }<F \leq F_{h}\right)$, míg a második csoportba tartozó forgalmi ráterheléseket kitöltetlen pontok $\left(F_{h} \leq F<F_{\max }\right)$ jelölik. A mért átlagos utazási idő-forgalomnagyság és sebesség-forgalomnagyság összefüggésekre illesztett függvények a teljes vizsgálati tartományt tekintve nem folytonosak, az alkalmazott metódus azonban alkalmas a vizsgálat lefolytatásához. A forgalmi jellemzők közötti kapcsolatot a közúthálózat kialakítása jelentősen befolyásolja a vizsgált esetekben. Emiatt nem a vizsgált hálózatok forgalomlefolyási görbéjének egységes leírása, hanem az összehasonlító elemzése volt a kutatás célja.

Vizsgált tényezők közül a fajlagos utazási idő-átlagos sebesség kapcsolat esetében is az alábbi alakú exponenciális függvényt illesztettem az eredményekre.

$\mathrm{y}=y_{0}+A_{1} e^{-x / t_{1}}+A_{2} e^{-x / t_{2}}+A_{3} e^{-x / t_{3}}$

Az eredményeket a 6. ábra tartalmazza és minden esetben közel azonos lefutást követnek az eredményekre. Megfigyelhető, hogy a vizsgálatra kiválasztott utcahálózatok típusától és azok alkotóelemeinek a forgalomra gyakorolt hatásától az eredmények csak kis mértékben függenek. Az eredményekre illesztett harmadrangú exponenciális függvény 0,95-nél magasabb korrelációval rendelkezik. 
Az átlagos csomóponti időveszteség vizsgálata során különösen kijárati csomópontokon jelentkező áthaladási időveszteségek esetében megfigyelhető volt az áthaladási időveszteség exponenciális felfutása, amelyet a 7. ábra tartalmaz.

\subsection{FORGALMI VIZSGÁLAT EREDMÉNYEI}

A kutatás során kapott eredmények feldolgozása az alábbi 8 utcahálózati paraméter alapján történt, amelyeket 6 csoportba soroltam a vizsgálat kiértékelése során és a 1. táblázat tartalmaz

1. táblázat: Vizsgálatra kiválasztott utcahálózati modellek csoportosítása

\begin{tabular}{|c|c|c|c|}
\hline \multirow{2}{*}{$\begin{array}{l}\text { Paraméter vizsgálat } \\
\text { (vizsgálat célja) }\end{array}$} & \multirow[t]{2}{*}{ Felhasznált modellek } & \multicolumn{2}{|c|}{$\begin{array}{c}\text { Vizsgálatra kiválasztott modellek jellemzése } \\
\text { (vizsgálat paraméterek) }\end{array}$} \\
\hline & & Azonos paraméter & Eltérő paraméter \\
\hline $\mathrm{A}$ & $\mathrm{B}$ & C & $\mathrm{D}$ \\
\hline $\begin{array}{l}\text { I. } \\
\text { Ugyanolyan alakú, de eltérő } \\
\text { méretü területek vizsgálata }\end{array}$ & $\begin{array}{l}\text { - s8_1000_8x8 } \\
\text { - s8_391_5x5 } \\
\text { - s8_563_6x6 } \\
\text { - s8_766_7x7 }\end{array}$ & $\begin{array}{l}\text { - Kijárati csomópontok } \\
\text { elhelyezkedése } \\
\text { - Kijárati csomópontok } \\
\text { száma } \\
\text { - Kijárati csomópontok } \\
\text { kijárati csomóponti } \\
\text { ágszáma } \\
\text { - Terület alakja } \\
\text { - Belső utcahálózati } \\
\text { raszter } \\
\text { - Gyűjtőút } \\
\text { elhelyezkedése } \\
\text { - Egyirányúsítás }\end{array}$ & - Terület mérete \\
\hline $\begin{array}{l}\text { II. } \\
\text { Eltérö alakú területek } \\
\text { vizsgálata }\end{array}$ & 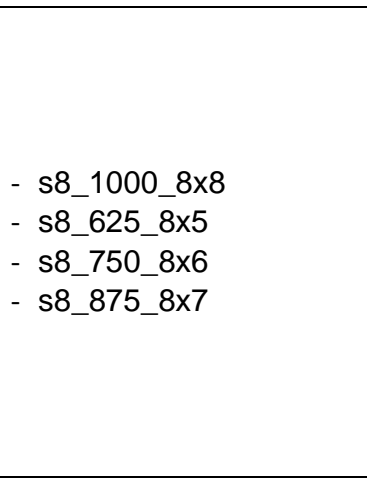 & $\begin{array}{l}\text { - Kijárati csomópontok } \\
\text { elhelyezkedése } \\
\text { - Kijárati csomópontok } \\
\text { száma } \\
\text { - Kijárati csomópontok } \\
\text { kijárati csomóponti } \\
\text { ágszáma } \\
\text { - Belső utcahálózati } \\
\text { raszter } \\
\text { - Gyűjtőút } \\
\text { elhelyezkedése } \\
\text { - Egyirányúsítás }\end{array}$ & $\begin{array}{l}\text { - Terület mérete } \\
\text { - Terület alakja }\end{array}$ \\
\hline $\begin{array}{l}\text { III. } \\
\text { Kijárati csomópontok } \\
\text { számának és } \\
\text { elhelyezkedésének } \\
\text { vizsgálata }\end{array}$ & $\begin{array}{l}\text { - s8_1000_8x8 } \\
\text { - e3_1000_8x8 } \\
\text { - e4_1000_8x8 } \\
\text { - s3_1000_8x8 } \\
\text { - s4_1000_8x8 } \\
\text { - s6_1000_8x8 }\end{array}$ & $\begin{array}{l}\text { - Terület mérete } \\
\text { - Terület alakja } \\
\text { - Belső utcahálózati } \\
\text { raszter } \\
\text { - Gyűjtőút } \\
\text { elhelyezkedése } \\
\text { - Egyirányúsítás }\end{array}$ & $\begin{array}{l}\text { - Kijárati } \\
\text { csomópontok } \\
\text { elhelyezkedése } \\
\text { - Kijárati } \\
\text { csomópontok } \\
\text { száma } \\
\text { - Kijárati } \\
\text { csomópontok } \\
\text { kijárati csomóponti } \\
\text { ágszáma }\end{array}$ \\
\hline \begin{tabular}{l}
\multicolumn{1}{c}{ IV. } \\
Belső utcahálózat \\
sürüségének vizsgálata
\end{tabular} & $\begin{array}{l}\text { - s8_1000_8x8 } \\
\text { - s8_1000_8x5 } \\
\text { - s8_1000_8x6 } \\
\text { - s8_1000_8x7 }\end{array}$ & $\begin{array}{l}\text { - Kijárati csomópontok } \\
\text { elhelyezkedése } \\
\text { - Kijárati csomópontok } \\
\text { száma } \\
\text { - Kijárati csomópontok } \\
\text { kijárati csomóponti } \\
\text { ágszáma } \\
\text { - Terület mérete } \\
\text { - Terület alakja }\end{array}$ & $\begin{array}{l}\text { - Belső utcahálózati } \\
\text { raszter }\end{array}$ \\
\hline
\end{tabular}




\begin{tabular}{|c|c|c|c|}
\hline & & $\begin{array}{l}\text { - Gyüjtőút } \\
\text { elhelyezkedése } \\
\text { - Egyirányúsítás }\end{array}$ & \\
\hline $\begin{array}{l}\text { Gyűjtőutak } \\
\text { elhelyezkedésének } \\
\text { vizsgálata }\end{array}$ & $\begin{array}{l}\text { - s8_1000_8x8 } \\
\text { - e4_1000_8x8 } \\
\text { - e4k_v0_1000_8x8 } \\
\text { - e4k_v1_1000_8x8 } \\
\text { - e4k_v2_1000_8x8 } \\
\text { - e4k_v3_1000_8x8 } \\
\text { - e4k_v4_1000_8x8 }\end{array}$ & $\begin{array}{l}\text { - Terület mérete } \\
\text { - Terület alakja } \\
\text { - Belső utcahálózati } \\
\text { raszter } \\
\text { - Egyirányúsítás }\end{array}$ & $\begin{array}{l}\text { - Kijárati } \\
\text { csomópontok } \\
\text { elhelyezkedése } \\
\text { - Kijárati } \\
\text { csomópontok } \\
\text { száma } \\
\text { - Kijárati } \\
\text { csomópontok } \\
\text { kijárati csomóponti } \\
\text { ágszáma } \\
\text { - Gyüjtőút } \\
\text { elhelyezkedése }\end{array}$ \\
\hline $\begin{array}{l}\text { VI. } \\
\text { Utcahálózat } \\
\text { egyirányúsításának } \\
\text { vizsgálata }\end{array}$ & $\begin{array}{l}\text { - s8_1000_8x8 } \\
\text { - s8_egy_1000_nr_8x8 } \\
\text { - s8_egy_1000_mr_8x8 } \\
\text { - s8_egy_1000_kr_8x8 }\end{array}$ & $\begin{array}{l}\text { - Kijárati csomópontok } \\
\text { elhelyezkedése } \\
\text { - Kijárati csomópontok } \\
\text { száma } \\
\text { - Kijárati csomópontok } \\
\text { kijárati csomóponti } \\
\text { ágszáma } \\
\text { - Terület mérete } \\
\text { - Terület alakja } \\
\text { - Belső utcahálózati } \\
\text { raszter } \\
\text { - Gyűjtőút } \\
\text { elhelyezkedése }\end{array}$ & - Egyirányúsítás \\
\hline
\end{tabular}

Az 1. táblázat sorai tartalmazzák a vizsgálati csoportosításokat. A táblázat $C$ és D oszlopában a vizsgálatra kiválasztott modelleket jellemeztem, dőlt betűvel emeltem ki a D oszlopban a kiválasztott modellek eltérö tulajdonságait. Az eredmények könnyebb összehasonlítása érdekében az alapmodellnek tekintettem az s8_8x8_1000 elnevezésủ modellt, amely mindegyik vizsgálati csoportnak a része. A forgalmat leíró jellemzők kiértékelése során az utcahálózati modellekhez tartozó eredményeket először grafikusan tartalmazza a cikk, majd ezt követi az eredmények szöveges kiértékelése. A kiértékelés során először az általános megállapításokat tartalmazza a cikk, jelölve a kapcsolódó csoportokat (pl.: I., II., VI. csoport), majd a csoportonként elemzés jelenik meg a cikkben azokban az esetekben, ahol egyedi tulajdonságok figyelhetők meg.

Néhány szóban szükséges megemlékezni a forgalmat leíró vizsgált jellemzők közötti összefüggések fontosságáról. Ilyen fontos szempontnak tekinthető a használt útvonalak aránya a rendelkezésre álló teljes hálózathoz képest, illetve azok kapacitáskihasználtsága a csomóponti áthaladási időveszteség mellett. Ezáltal változó nagyságú forgalmi terhelés hatására kialakuló forgalmi jellemzők, úm. sebesség és utazási idő, mögött jelentkező összefüggések egyértelmüsíthetők. Az eredmények kiértékelése során a vizsgált forgalomminőséget jellemző mennyiségek közötti kapcsolat megjelenik.

Az utcahálózaton megjelenő forgalmat ebben a kutatási lépésben makroszkopikus szintű forgalmi modellezési eljárással került elemzésre, azaz a forgalmi vizsgálat nem a hálózaton megjelenő jármüvenként került lemodellezésre, mint mikroszkopikus forgalmi ráterhelések (VISSIM szoftver) esetében, hanem matematikai egyenletek alapján. Ennek következtében csak olyan éleken jelent meg forgalom, amelyek hasznossága megfelelő, avagy nincsenek „kóborló” és útvonalkereső jármüvek a ráterhelési eredményekben.

A vizsgálatból származó eredmények grafikusan csak az I. vizsgálati csoport esetében kerültek ábrázolásra. Az eredményekből levont következtetéseket táblázatban foglaltam össze.

\subsection{1. ÁTLAGOS UTAZÁSI IDŐ ALAKULÁSA FORGALOMNAGYSÁG FÜGGVÉNYÉBEN}




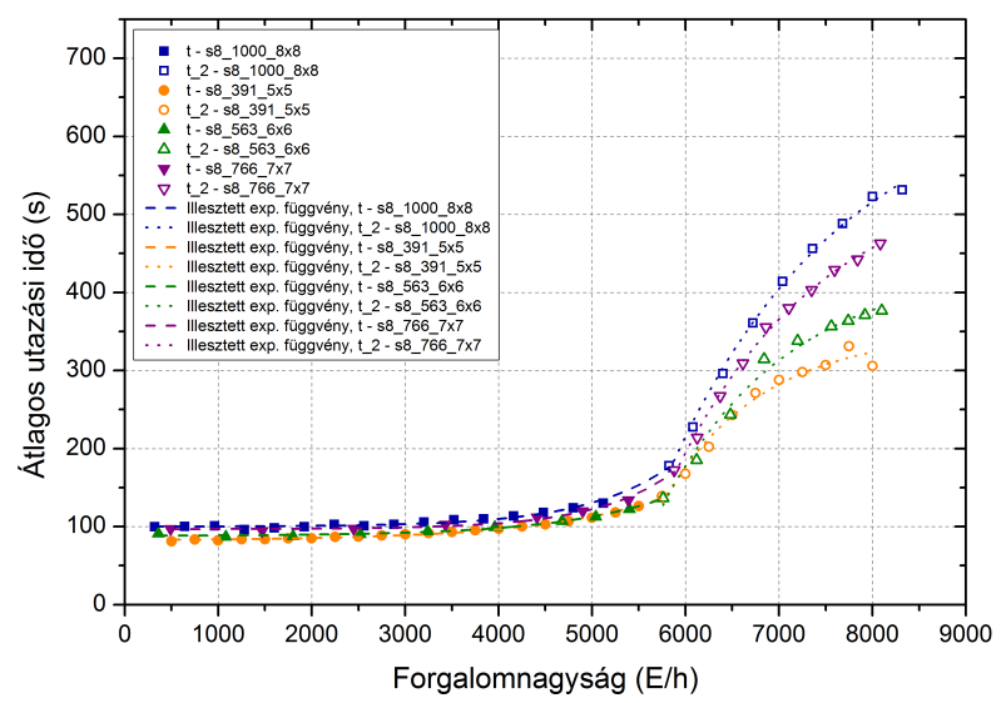

1. ábra: Átlagos utazási idő - forgalomnagyság összefüggési az I. csoport esetében.

A vizsgálat során elemzett átlagos utazási idő és forgalomnagyság közötti összefüggések eredményeit grafikusan az 1. ábra jeleníti meg, míg szövegesen a 2. táblázat tartalmazza összefoglalóan.

2. táblázat: Átlagos utazási idő - forgalomnagyság összefüggéseinek jellemzése

\begin{tabular}{|c|c|}
\hline Csoportosítás & Átlagos utazási idő - forgalomnagyság összefüggéseinek jellemzése \\
\hline $\begin{array}{l}\text { általános } \\
\text { észrevétel }\end{array}$ & $\begin{array}{l}\text { - Fh-nál kisebb forgalmi terhelés esetén az eredmények értéke közel azonos (I., II., III., IV., } \\
\text { VI. csoport). } \\
\text { - Fh-nál nagyobb forgalmi terhelés esetén, minél nagyobb méretű a hálózat, annál nagyobb } \\
\text { az utazási idő, azonos forgalomnagyság mellett (I., II., IV. csoport). A hosszabb bejárandó } \\
\text { útvonal következtében, illetve egyre több belső csomópontot érint a forgalom, amellyel a } \\
\text { csomóponti áthaladási időveszteség növekszik. } \\
\text { - Fh-nál nagyobb forgalmi terhelés esetén az eredmények eltérnek egymástól (I., II., III., IV., } \\
\text { V., Vl. csoport). A torlódás mértéke növekszik, illetve használat útszakaszok aránya } \\
\text { növekszik. } \\
\text { - Fh környezetében az átlagos utazási idő hirtelen megnö (III., V. csoport). }\end{array}$ \\
\hline I. csoport & - \\
\hline II. csoport & - \\
\hline III. csoport & $\begin{array}{l}\text { - Kijárati csomópontok száma, valamint azok összesített kapacitása minél alacsonyabb, Fh } \\
\text { értéke annál kisebb forgalom esetén jelentkezik. Azonos forgalomnagyság mellett } \\
\text { magasabb átlagos utazási idő figyelhető meg. Ezáltal a vizsgált terület elhagyására ezért } \\
\text { kisebb forgalmi kapacitás áll rendelkezésre az úthálózaton, és kijárati csomópontok } \\
\text { elhelyezkedése (él, sarok) minimálisan befolyásolja az eredményeket. } \\
\text { - Kijárati csomóponti ágak száma, valamint azok összesített kapacitása minél alacsonyabb, } \\
\text { Fh értéke annál kisebb forgalom esetén jelenik meg. Azonos forgalomnagyság mellett } \\
\text { magasabb átlagos utazási idő jelentkezik. Ezáltal a vizsgált területek elhagyására kisebb } \\
\text { forgalmi kapacitás áll rendelkezésre az úthálózaton. }\end{array}$ \\
\hline IV. csoport & $\begin{array}{l}\text { - Minél sürübb egy terület belső utcahálózata, annál nagyobb az utazási idő, azonos } \\
\text { forgalomnagyság mellett. Egyre több belső csomópontot érint a forgalom, a } \\
\text { csomópontokban jelentkező áthaladási időveszteség növekszik, amely érték nagyobb, mint } \\
\text { az utcaszakaszon jelentkező időveszteség. }\end{array}$ \\
\hline V. csoport & $\begin{array}{l}\text { - A vizsgálat eredményei közel megegyeznek egymással, ha a vizsgált területet feltáró } \\
\text { gyüjtőutak a terület hatáán található (határoló gyüjtőút az utcahálózati modell } 4 \text { oldalán), } \\
\text { vagy ha a terület belsejében vezetett az utcahálózati modellek függöleges és vízszintes } \\
\text { szimmetriatengelyén helyezkednek el (belső gyüjtóút), a kijárati csomópontok azonos } \\
\text { helyzete esetén. } \\
\text { - Az utcahálózatok belsejében áthaladó gyüjtőutak egymással alkotott csomópontjainak } \\
\text { távolságának növelése a terület súlypontjától növeli az utazási idöt. Többet kell a } \\
\text { jármüveknek csökkentett sebességü területeken haladnia. A hálózat forgalmi teljesítménye }\end{array}$ \\
\hline
\end{tabular}




\begin{tabular}{|c|c|}
\hline & $\begin{array}{l}\text { legkisebb, amikor a terület belsejében haladó gyüjtöutak elérik a terület határát (terület } 2 \\
\text { oldalán gyüjtöút). }\end{array}$ \\
\hline VI. csoport & $\begin{array}{l}\text { Fh-nál alacsonyabb forgalmi terheléskor a vizsgált utcahálózati modellek közötti eltérés } \\
\text { minimális. } \\
\text { Fh-nál nagyobb forgalom terheléskor az utazási idő növekedését tekintve növekvő } \\
\text { sorrendben egymást követi a négyzetes-, Malcher- és körös-rendszerü egyirányú forgalmi } \\
\text { renddel rendelkező vizsgált modellek. }\end{array}$ \\
\hline
\end{tabular}

\subsection{2. ÁtLAGOS SEBESSÉG ALAKULÁSA A FORGALOMNAGYSÁG FÜGGVÉNYÉBEN}

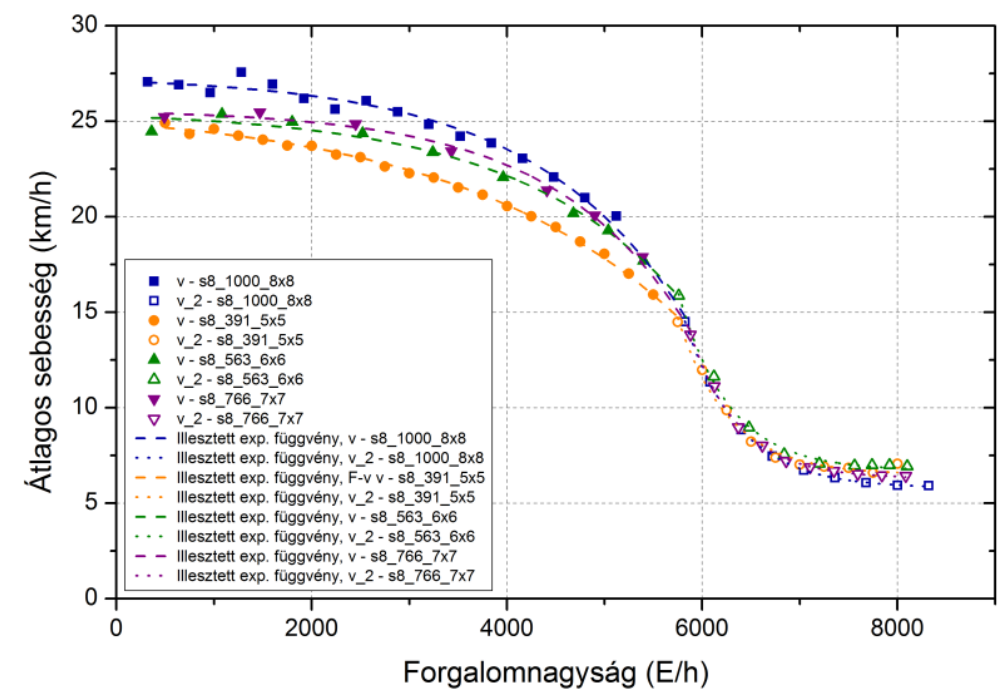

2. ábra: Átlagos sebesség - forgalomnagyság összefüggési az I. csoport esetében.

A vizsgálat során elemzett átlagos sebesség és forgalomnagyság közötti összefüggések eredményeit grafikusan a 2. ábra jeleníti meg, míg szövegesen a 3. táblázat tartalmazza összefoglalóan.

3. táblázat: Átlagos sebesség - forgalomnagyság összefüggéseinek jellemzése

\begin{tabular}{|c|c|}
\hline Csoportosítás & Átlagos sebesség - forgalomnagyság összefüggéseinek jellemzése \\
\hline $\begin{array}{l}\text { általános } \\
\text { észrevétel }\end{array}$ & $\begin{array}{l}\text { - Fh-nál kisebb forgalom esetén, minél hosszabb a terület utcahálózata, illetve nagyobb az } \\
\text { modell területe, annál nagyobb az átlagos sebesség értéke Azonos forgalomnagyság } \\
\text { mellett (I., II., IV. csoport) arányaiban több jármü használja a gyűjtőutakat. } \\
\text { - Fh-nál nagyobb forgalom esetén eltünik az eredmények közötti kezdeti különbség (I., II., } \\
\text { IV., VI. csoport). A kisebb utcahálózatok esetén nagyobb az utazási sebesség, kisebb } \\
\text { torlódás alakul ki a hálózaton. Kevesebb csomópontot érint a hálózaton megjelenő } \\
\text { forgalom, illetve alacsonyabb a csomóponti áthaladási időveszteség. } \\
\text { - Fh környezetében az átlagos sebesség kis forgalmi terhelés hatására hirtelen csökken (III., } \\
\text { V. csoport) }\end{array}$ \\
\hline I. csoport & - \\
\hline II. csoport & - \\
\hline III. csoport & $\begin{array}{l}\text { - Kijárati csomópontok helyzete alapján } F_{h} \text {-nál kisebb forgalomnagyság mellett sarkokban } \\
\text { elhelyezkedő csomópontont esetén nagyobb átlagos sebesség alakul ki a hálózaton, mint } \\
\text { élek mentén elhelyezkedő csomópontok esetében. Amennyiben az utcahálózat minél több } \\
\text { kijárati csomóponttal rendelkezik, úgy Fh értéke annál nagyobb forgalom mellett } \\
\text { jelentkezik. Amennyiben a kijárati csomóponti ágak száma, valamint azok összegzett } \\
\text { forgalmi kapacitása állandó. } \\
\text { - Kijárati csomóponti ágak száma, valamint azok összesített kapacitása befolyásolja a } \\
\text { forgalmi jellemzőket. Amennyiben a kijárati csomóponti ágak száma, valamint azok } \\
\text { összegzett forgalmi kapacitása minél nagyobb, annál nagyobb átlagos sebesség alakul ki } \\
\text { az utcahálózaton, a kijárati csomópontok azonos helyzete mellett. }\end{array}$ \\
\hline IV. csoport & $\begin{array}{l}\text { - Fh-nál nagyobb forgalom esetén a legritkább utcahálózaton jelentkezik a legnagyobb } \\
\text { átlagos sebesség. Az eredmények közötti különbség összefügg a 'használt utcaszakaszok } \\
\text { aránya' és a 'használt utcaszakaszok kapacitáskihasználtsága' közötti különbséggel. }\end{array}$ \\
\hline
\end{tabular}




\begin{tabular}{|c|c|}
\hline V. csoport & $\begin{array}{l}\text { - Fh-nál kisebb forgalomi terhelés esetén az utcahálózatok belsejében áthaladó gyüjtőutak } \\
\text { egymással alkotott csomópontjainak távolságának növelése a terület súlypontjától } \\
\text { csökkenti az átlagos sebesség értékét. } \\
\text { - Fh-nál nagyobb forgalmi ráterhelés esetében az azonos kijárati csomópontszámmal és } \\
\text { kijárati csomóponti ágszámmal rendelkező utcahálózatoknál a vizsgált modellekhez tartozó } \\
\text { forgalomminőségi jellemzö közel azonos értékkel rendelkezik } \\
\text { - A csoporton belüli többi vizsgálati esettel azonos számú kijárati csomóponti ágszámmal, } \\
\text { de kevesebb kijárati csomóponttal rendelkező e4_v4k_1000_8x8 utcahálózati modell } \\
\text { eredményei alacsonyabb értéket vesznek fel a többi esetnél. }\end{array}$ \\
\hline VI. csoport & $\begin{array}{l}\text { - Fh-nál kisebb forgalomnagyságnál az egyirányú utcákból álló hálózatok alacsonyabb az } \\
\text { átlagos sebesség értékkel rendelkeznek, minta mindkét irányból járható utcákból felépült } \\
\text { hálózatok. Az egyirányú kialakítások esetében a hálózatokon kifejtett sebesség csökkenő } \\
\text { sorrendben "négyzetes-, Malcher-, körös-rendszer". Fh-nál nagyobb forgalmi ráterheléskor } \\
\text { a vizsgált utcahálózatokhoz tartozó eredmények közel azonosak. }\end{array}$ \\
\hline
\end{tabular}

\subsubsection{HASZNÁLT UTCAHÁLÓZAT ARÁNYA A TELJES UTCAHÁLÓZATHOZ VISZONYÍTVA A} FORGALOMNAGYSÁG FÜGGVÉNYÉBEN

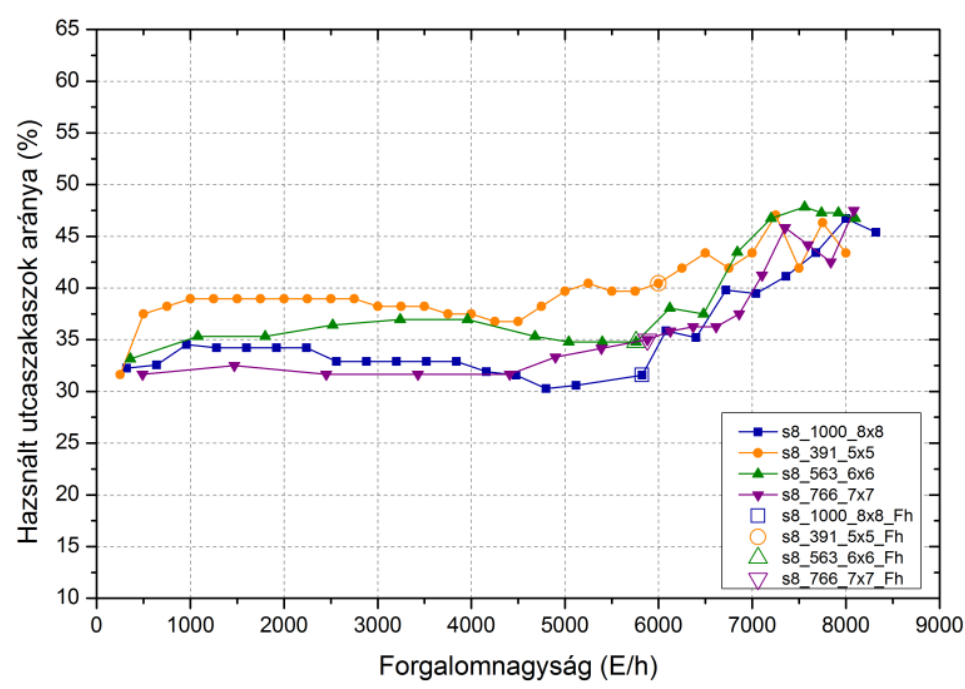

3. ábra: Használt utcaszakaszok aránya a teljes utcahálózathoz viszonyítva a forgalomnagyság függvényében az I. csoport esetében.

A vizsgálat során elemzett használt utcaszakaszok aránya a teljes utcahálózathoz viszonyítva a forgalomnagyság függvényében vizsgálat eredményeit grafikusan a 3. ábra jeleníti meg, míg szövegesen a 4. táblázat tartalmazza összefoglalóan.

4. táblázat: Használt utcahálózat aránya a teljes utcahálózathoz viszonyítva - forgalomnagyság összefüggéseinek jellemzése

\begin{tabular}{|c|c|}
\hline Csoportosítás & $\begin{array}{c}\text { Használt utcahálózat aránya a teljes utcahálózathoz viszonyítva - forgalomnagyság } \\
\text { összefüggéseinek jellemzése }\end{array}$ \\
\hline $\begin{array}{l}\text { általános } \\
\text { észrevétel }\end{array}$ & $\begin{array}{l}\text { - Fh-nál kisebb forgalmi terhelés esetén a használt utcaszakaszok aránya közel állandó (I., } \\
\text { II., III., IV., V., VI. csoport). Ezekben az esetekben a járművek által használt } \\
\text { utcaszakaszokon nem alakul ki torlódás, az utazási idő és sebesség közel állandó. A } \\
\text { hálózaton közlekedő járművek nem keresnek új útvonalat. } \\
\text { - Fh-nál nagyobb forgalmi terhelés esetén a használt utcaszakaszok aránya a növekvő } \\
\text { forgalmi terhelés hatására folyamatosan nő (I., II., III., IV., V., VI. csoport). Minél nagyobb } \\
\text { az utazási idő növekedése a használt utcaszakaszokon, annál nagyobb lesz a használt } \\
\text { utcaszakaszok aránya. A kedvezőbb utazási idő érdekében a forgalom szétterül a } \\
\text { hálózaton. A kialakuló torlódások hatására megnövekedett utazási idő új útvonalak } \\
\text { használatára terelik a közlekedőket. A torlódás növekedése azt jelenti a használt } \\
\text { utcaszakaszok állandósult értéke mellett, hogy a járművek újabb utcaszakaszokat nem } \\
\text { érintenek. A hálózatokon a forgalom szétterülése egy maximális értéket vesz fel, amely az } \\
\text { utazási idő szempontjából optimálisnak tekinthető. }\end{array}$ \\
\hline
\end{tabular}




\begin{tabular}{|c|c|}
\hline & $\begin{array}{l}\text { - A használt utcaszakaszok aránya a változó nagyságú forgalmi terhelések mellett } \\
\text { maximálisan } 50 \% \text { körüli használati arányt mutatnak (I., II., III., IV., V., VI. csoport). Az } \\
\text { utcahálózati modellek tartalmaznak olyan éleket, amelyeken nem jelenik meg forgalom a } \\
\text { makroszkopikus szemléletü forgalmi vizsgálat miatt. } \\
\text { - Az utcahálózatok méretének hatása az eredményekben nem jelenik meg egyértelműen (I., } \\
\text { II., IV. csoport). }\end{array}$ \\
\hline I. csoport & - \\
\hline II. csoport & - \\
\hline III. csoport & $\begin{array}{l}\text { - Fh-nál kisebb forgalomnagyságok esetén azonos forgalomnagyság mellett a sarkokban } \\
\text { elhelyezkedő kijárati csomópontok esetén magasabb a használt útszakaszok aránya, mint } \\
\text { élek menti elhelyezkedő csomópontoknál. Minél több kijárati csomóponttal rendelkezik a } \\
\text { hálózat, valamint azok összegzett kapacitása minél nagyobb, annál magasabb a használt } \\
\text { utcaszakaszok aránya azonos forgalomnagyság mellett. Minél több kijárati csomóponti } \\
\text { ággal rendelkezik a hálózat, valamint azok összegzett kapacitása minél nagyobb, annál } \\
\text { magasabb a használt utcaszakaszok aránya azonos forgalmi terhelés mellett. } \\
\text { - A felsorolt megfigyeléseket indokolják, hogy a kijárati csomópontok száma növelésével a } \\
\text { forgalom szétterül a hálózaton. Minél aszimmetrikusabb a hálózat a kijárati csomópontok } \\
\text { elhelyezkedése alapján (3 db sarok mentén vagy élek mentén elhelyezkedő csomópontok), } \\
\text { annál csatornázottabban jelenik meg a forgalom a hálózaton. Sarkokban elhelyezkedő } \\
\text { kijárati csomópontok jobban szét tudják teríteni a hálózati forgalmat, mint az élek mentén } \\
\text { elhelyezkedő kijárati csomópontok. Kijárati csomóponti ágak összesített kapacitása } \\
\text { befolyásolja a hálózati forgalomlefolyást. } \\
\text { - Az utcahálózati modellek eredményei egymás közötti sorrendje az Fn-nál nagyobb mértékű } \\
\text { forgalmi terhelést követően megváltozik. A kijárati csomópontok száma minél kevesebb, } \\
\text { valamint azok összegzett kapacitása minél alacsonyabb, annál magasabb a használt } \\
\text { utcaszakaszok aránya, illetve annál magasabb a használt utcaszakaszok aránya, és azok } \\
\text { értéke élek mentén elhelyezkedő kijárati csomópontok esetén magasabb, mint sarok } \\
\text { mentén elhelyezkedő kijárati csomópont esetén. }\end{array}$ \\
\hline IV. csoport & - \\
\hline V. csoport & $\begin{array}{l}\text { - Fh-nál kisebb forgalmi terhelés esetén a gyűjtőút elhelyezkedése nem gyakorol jelentős } \\
\text { hatást az eredményekre. Fh értékkel közel megegyező forgalmi terheléskor a belső gyűjtőút } \\
\text { és a kijárati csomópontok elhelyezkedése az eredményekben kezd megjelenni. Az } \\
\text { utcahálózatok belsejében elhelyezkedő gyűjtőutak minél távolabb helyezkedik el terület } \\
\text { súlypontjától, annál magasabb a használt utcaszakaszok aránya. } \\
\text { - Fh környezetében kis forgalmi növekmény hatására jelentősen megnövekszik a használt } \\
\text { utcaszakaszok aránya. } \\
\text { - Fh forgalomnagyságnál nagyobb forgalmi terhelések hatására az utcahálózatok belsejében } \\
\text { áthaladó gyűjtőutak egymással alkotott csomópontjainak távolságának növelése a terület } \\
\text { középpontjától növeli a használt utcaszakaszok arányát és azok kapacitáskihasználtságát. } \\
\text { A hálózatokon közel azonos mértékü torlódás alakul ki, de a használt utcaszakaszok } \\
\text { kapacitáskihasználtságában jelentős különbség adódik. }\end{array}$ \\
\hline VI. csoport & $\begin{array}{l}\text { - Fh-nál kisebb forgalom esetén a "Malcher-rendszer"-nál alacsonyabb a használt } \\
\text { utcaszakaszok aránya, mint "négyzetes- és körös-rendszer" esetekben. Illetve ezek az } \\
\text { értékek egyirányúsítással rendelkező utcahálózatok esetében magasabbak, mint kétirányú } \\
\text { belső utcahálózati modell (s8_1000_8x8) esetében. A használt utcaszakaszok számának } \\
\text { magasabb használtsága a rendelkezésre álló útszakaszok alacsonyabb számának } \\
\text { köszönhető. } \\
\text { - Fh-nál nagyobb forgalmi terhelés esetén a "körös-rendszerhez" tartozik a legmagasabb a } \\
\text { használt utcaszakaszok aránya az egyirányú utcahálózatok között. Az egyirányú } \\
\text { utcakialakításhoz tartozó eredmények magasabbak, mint a kétirányú belső utcahálózattal } \\
\text { rendelkező modell értékei. Az eredmény összefügg a használt útszakaszokon kialakuló } \\
\text { torlódás hosszával, a torlódott és a használt útszakaszok arányával és a használt } \\
\text { útszakaszok kapacitáskihasználtságával. }\end{array}$ \\
\hline
\end{tabular}

\subsubsection{HASZNÁLT UTCASZAKASZOKON KIALAKULÓ TORLÓDÁS HOSSZA ÉS TORLÓDOTT ÉS A HASZNÁLT UTCASZAKASZOK ARÁNYA A FORGALOMNAGYSÁG FÜGGVÉNYÉBEN}




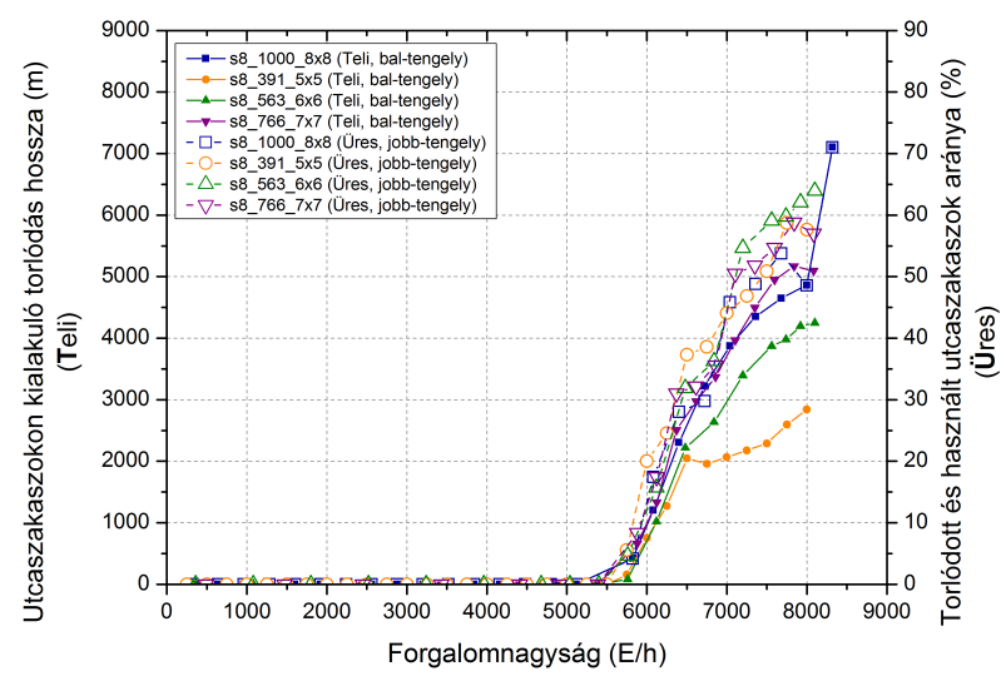

4. ábra: Használt utcaszakaszokon kialakuló torlódás hossza-forgalomnagyság, és torlódott és a használt utcaszakaszok aránya-forgalomnagyság összefüggése az I. csoport esetében.

A vizsgálat során elemzett használt utcaszakaszokon kialakuló torlódás hossza-forgalomnagyság, és a torlódott és a használt utcaszakaszok aránya-forgalomnagyság közötti összefüggések eredményeit grafikusan a 4. ábra jeleníti meg, míg szövegesen a 5. táblázat tartalmazza összefoglalóan.

5. táblázat: Használt utcaszakaszokon kialakuló torlódás hossza-forgalomnagyság, és torlódott és a használt utcaszakaszok aránya-forgalomnagyság közötti összefüggések jellemzése

\begin{tabular}{|c|c|}
\hline Csoportosítás & $\begin{array}{l}\text { Használt utcaszakaszokon kialakuló torlódás hossza, és a torlódott és a használt } \\
\text { utcaszakaszok aránya - forgalomnagyság közötti összefüggéseinek jellemzése }\end{array}$ \\
\hline $\begin{array}{l}\text { általános } \\
\text { észrevétel }\end{array}$ & $\begin{array}{l}\text { - Fh-nál kisebb forgalmi terheléskor nem alakul ki torlódás a hálózatokon, míg Fh-nál } \\
\text { nagyobb forgalmi terhelés esetén fokozatosan növekszik mind a hálózaton kialakuló } \\
\text { torlódások hossza, mind pedig a torlódott és a jármüvek által használt utcaszakaszok } \\
\text { aránya (I., II., III., IV., V., VI. csoport). } \\
\text { - A hálózatok eltérö felépitése és a kialakítása miatt nem elegendő csak a torlódás hosszát } \\
\text { figyelembe venni. A torlódott és a használt utcaszakaszok aránya alapján láthatóvá válik a } \\
\text { vizsgált utcahálózatok hasonló viselkedése torlódott állapotban (I., II., III., IV., V., } \\
\text { VI. csoport). } \\
\text { - Kisebb hálózatokon rövidebb torlódás alakul ki, de a torlódott és használt utcaszakaszok } \\
\text { aránya alapján azonosan alakul a forgalom lefolyása, modellek területének mértékétöl } \\
\text { függetlenül, a kijárati csomópontok és a kijárati csomóponti ágak azonos száma és } \\
\text { elhelyezkedése esetén (I., II., IV. csoport). } \\
\text { - Torlódások közel azonos forgalomnagyság esetén kezd el kialakulni Fh környezetében (I., } \\
\text { II., IV. csoport). }\end{array}$ \\
\hline I. csoport & $\begin{array}{l}\text { - A legkisebb hálózat esetében (s5_391_8x8) Fn-t meghaladó terheléskor a torlódás } \\
\text { kialakulásának tendenciája megváltozik, kisebb mértékben növekszik, mint a többi vizsgált } \\
\text { eset. Torlódások az utcahálózatokon Fh-t meghaladó forgalmi terheléskor közel azonosan } \\
\text { alakulnak. } \\
\text { - A legnagyobb hálózat esetében (s8_1000_8x8) a legmagasabb forgalmi terheléskor } \\
\text { hirtelen megnő a torlódás hossza, ugyanakkor a használt utcaszakaszok aránya } \\
\text { lecsökken. A torlódott és használt utcaszakaszok arányát tekintve az eredmények } \\
\text { átlagosan a többi vizsgált modellhez illeszkednek. }\end{array}$ \\
\hline II. csoport & - \\
\hline III. csoport & 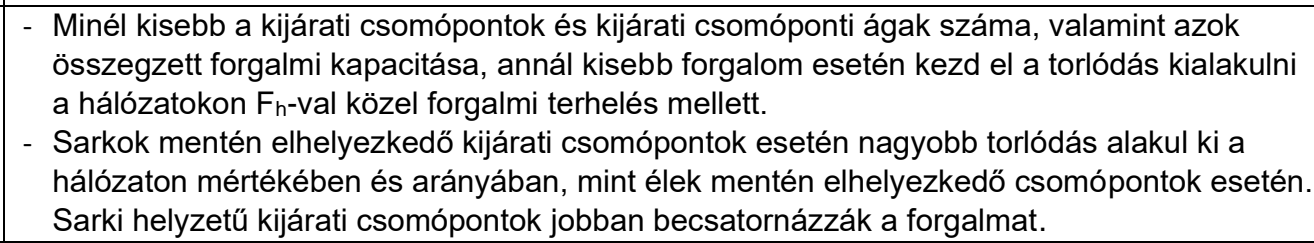 \\
\hline IV. csoport & \\
\hline
\end{tabular}




\begin{tabular}{|c|c|}
\hline V. csoport & $\begin{array}{l}\text { Területet feltáró gyüjtőút elhelyezkedése a torlódás alakulása szempontjából nem } \\
\text { releváns, azonos számú kijárati csomóponttal és kijárati csomóponti ággal rendelkező } \\
\text { modellek esetén. } \\
\text { A e4k_v4_1000_8x8 utcahálózati eset } 3 \text { kijárati csomópontot és } 4 \text { kijárati csomóponti ágat } \\
\text { tartalmaz. E modell esetén nagyobb torlódás alakul ki azonos forgalomnagyság mellett a } \\
\text { hálózaton, mint a vizsgálati csoport többi eleme esetében. }\end{array}$ \\
\hline VI. csoport & $\begin{array}{l}\text { A vizsgált utcahálózatokon kialakuló torlódás hossza a teljes vizsgálati tartományban közel } \\
\text { azonosan alakulnak A legnagyobb forgalmi ráterhelésekor a „körös” rendszerben kisebb az } \\
\text { utcahálózaton kialakuló torlódás értéke, mint a másik három esetben. } \\
\text { Egyirányú utcaszakaszokat tartalmazó hálózatok között a torlódott és a használt } \\
\text { utcaszakaszok aránya között nem alakul ki jelentös különbség és a kétirányú } \\
\text { utcahálózattal közel azonosan alakul. }\end{array}$ \\
\hline
\end{tabular}

\subsubsection{HASZNÁLT UTCASZAKASZOK KAPACITÁSKIHASZNÁLTSÁGA A FORGALOMNAGYSÁG FÜGGVÉNYÉBEN}

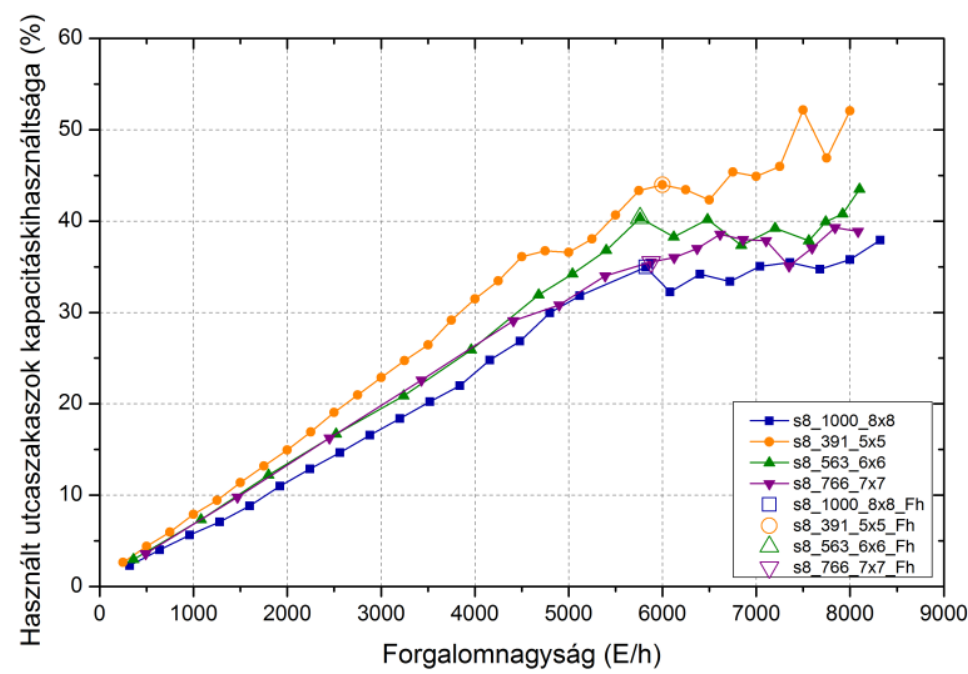

5. ábra: Használt utcaszakaszok átlagos kapacitáskihasználtsága a forgalomnagyság függvényében az I. csoport esetében.

A vizsgálat során elemzett használt utcaszakaszok átlagos kapacitáskihasználtsága és forgalomnagyság közötti összefüggések eredményeit grafikusan az 5. ábra jeleníti meg, míg szövegesen a 6. táblázat tartalmazza összefoglalóan.

6. táblázat: Használt utcaszakaszok átlagos kapacitáskihasználtsága - forgalomnagyság összefüggéseinek jellemzése

\begin{tabular}{|c|c|}
\hline Csoportosítás & $\begin{array}{c}\text { Használt utcaszakaszok kapacitáskihasználtsága - forgalomnagyság } \\
\text { összefüggéseinek jellemzése }\end{array}$ \\
\hline $\begin{array}{l}\text { általános } \\
\text { észrevétel }\end{array}$ & $\begin{array}{l}\text { - Fh-nál kisebb forgalom esetén a használt utcaszakaszok kapacitáskihasználtsága } \\
\text { szigorúan monoton növekszik, azt követően csak tendenciájában növekedik a } \\
\text { kapacitáskihasználtság (I., II., III., IV., V., VI. csoport). } \\
\text { - minél kisebb egy utcahálózat a területe a hálózatot felépítő utcák összesített hossza és } \\
\text { darabszáma alapján, a használt utcaszakaszok kapacitáskihasználtsága annál magasabb } \\
\text { azonos forgalomnagyság mellett (I., II., IV. csoport). } \\
\text { - legnagyobb forgalmi terhelés mellett a használt utcaszakaszok kapacitáskihasználtsága } \\
40 \% \text { körül adódik (I., II., IV. csoport). }\end{array}$ \\
\hline I. csoport & 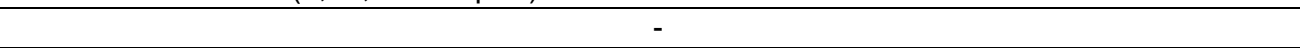 \\
\hline II. csoport & - \\
\hline III. csoport & $\begin{array}{l}\text { - Fh-nál kisebb forgalom esetén a sarkokban elhelyezkedő kijárati csomópontokat tartalmazó } \\
\text { modellekhez magasabb kapacitáskihasználtság tartozik, mint élek mentén elhelyezkedő } \\
\text { kijárati csomópontok esetén. Minél kevesebb kijárati csomóponttal rendelkezik egy hálózat, } \\
\text { valamint azok összegzett forgalmi kapacitása minél kisebb azonos forgalomnagyság } \\
\text { mellett, annál magasabb a használt utcaszakaszok kapacitáskihasználtsága. }\end{array}$ \\
\hline
\end{tabular}




\begin{tabular}{|c|c|}
\hline & $\begin{array}{l}\text { - Fh-t meghaladó forgalom esetén azonos forgalomnagyság mellett minél több kijárati } \\
\text { csomóponti ággal rendelkezik az utcahálózati modell. Azok összesített kapacitása, annál } \\
\text { magasabb az utcaszakaszok kapacitáskihasználtság azonos kijárati csomópontszám és } \\
\text { azok elhelyezkedése esetén. A kijárati csomópontok sarki helyzete esetén magasabb az } \\
\text { utcaszakaszok kapacitáskihasználtsága, mint élek mentén elhelyezkedő csomópontok } \\
\text { esetében. Azonos forgalomnagyság mellett, a kijárati csomópontok száma minél } \\
\text { magasabb, valamint azok összesített kapacitása minél nagyobb, annál alacsonyabb a } \\
\text { használt utcaszakaszok kapacitáskihasználtsága. }\end{array}$ \\
\hline IV. csoport & - \\
\hline V. csoport & $\begin{array}{l}\text { - Az utcahálózatok belsejében áthaladó gyűjtőutak egymással alkotott csomópontjainak } \\
\text { távolságának növelése a terület súlypontjától növeli a használt utcaszakaszok } \\
\text { kapacitáskihasználtsága. }\end{array}$ \\
\hline VI. csoport & $\begin{array}{l}\text { - Fh-nál kisebb forgalom esetén az egyirányú kialakítással rendelkező utcahálózatok közötti } \\
\text { eredmény növekvő sorrendben „körös-, négyzetes- és Malcher-rendszer”, illetve az „alap” } \\
\text { kétirányú utcahálózaton a használt utcaszakaszok kapacitáskihasználtsága a } \\
\text { legalacsonyabb, illetve 4000E/h forgalmi terhelést meghaladó forgalmi terhelés esetén a } \\
\text { „körös- és a négyzetes-rendszer” között helyezkedik el. } \\
\text { - Fh-nál nagyobb forgalom esetén jelentkezik az egyirányú utcaszakaszok csatornázottsága } \\
\text { az utcaszakaszok magasabb kapacitáskihasználtságban. Amely érték jelentősen nagyobb } \\
\text { lesz, mint kétirányú belső utcahálózattal rendelkező esetben. A „Malcher- és négyzetes- } \\
\text { rendszerhez” nagyobb kapacitáskihasználtság tartozik, mint „körös-rendszerhez”. } \\
\text { Mindegyik egyirányú esetben a használt utcaszakaszok kapacitáskihasználtsága } \\
\text { magasabb, mint az alap, kétirányú belső utcahálózattal rendelkező modell esetén. }\end{array}$ \\
\hline
\end{tabular}

\subsubsection{FAJLAGOS UTAZÁSI IDŐ ALAKULÁSA AZ ÁTLAGOS SEBESSÉG FÜGGVÉNYÉBEN}

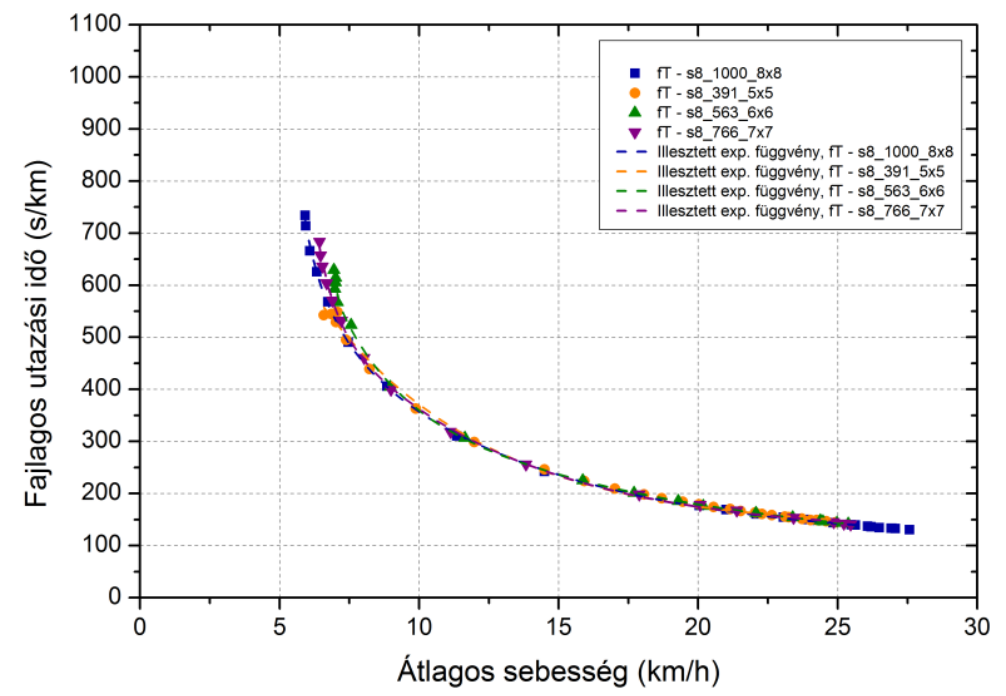

6. ábra: Fajlagos utazási idő - átlagos sebesség összefüggés az I. csoport esetében.

A vizsgálat során elemzett fajlagos utazási idő és átlagos sebesség közötti összefüggések eredményeit grafikusan a 6. ábra jeleníti meg, míg szövegesen a 7. táblázat tartalmazza összefoglalóan. A vizsgálatból származó eredmények közel azonosak, a vizsgálati csoportokhoz tartozó kiértékelést emiatt nem készítettem.

\section{7. táblázat: Fajlagos utazási idő - átlagos sebesség jellemzése}

\begin{tabular}{|l|l|}
\hline Csoportosítás & \multicolumn{1}{|c|}{ Fajlagos utazási idő - átlagos sebesség összefüggéseinek jellemzése } \\
\hline \multirow{2}{*}{ általános } & $\begin{array}{l}\text { - Vizsgált modellek eredményeiben a geometriai különbségek nem jelentkeznek, minden } \\
\text { eredményre közel azonos görbe illeszthető (I., II., III., IV., V., VI. csoport). A közlekedök } \\
\text { fajlagos utazási ideje és átlagos sebessége között szoros összefüggés van függetlenül } \\
\text { az úthálózat geometriájától. }\end{array}$ \\
\hline
\end{tabular}




\subsection{7. ÁTLAGOS CSOMÓPONTI ÁTHALADÁSI IDŐVESZTESÉG ALAKULÁSA KIJÁRATI CSOMÓPONTOK ESETÉBEN}

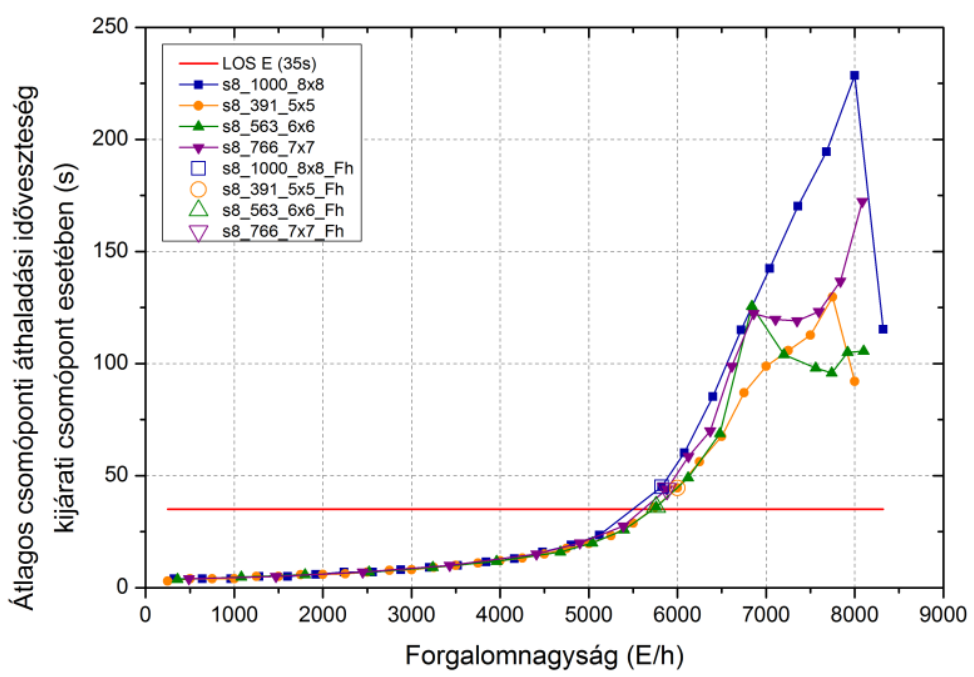

7. ábra: Átlagos csomóponti áthaladási időveszteség kijárati csomópontok (körforgalmak) esetén a forgalomnagyság függvényében az l. csoportot tekintve.

A vizsgálat során elemzett átlagos csomóponti áthaladási időveszteség a kijárati csomópontban és a hálózati forgalomnagyság közötti összefüggés eredményeit grafikusan a 7. ábra jeleníti meg, míg szövegesen a 8. táblázat tartalmazza összefoglalóan.

8. táblázat: Átlagos csomóponti áthaladási időveszteség kijárati csomópontok esetében - forgalomnagyság összefüggéseinek jellemzése

\begin{tabular}{|c|c|}
\hline Csoportosítás & $\begin{array}{c}\text { Átlagos csomóponti áthaladási időveszteség kijárati csomópontok esetében - } \\
\text { forgalomnagyság összefüggéseinek jellemzése }\end{array}$ \\
\hline $\begin{array}{l}\text { általános } \\
\text { észrevétel }\end{array}$ & $\begin{array}{l}\text { - Kijárati csomópontok „B” vagy „C” szolgáltatási szinttel rendelkeznek } \\
\text { maximálisan, ahol a kijárati csomóponti ágak összesített kapacitása alacsonyabb, } \\
\text { mint a hálózaton megjelenő forgalom nagysága (III., V. csoport). Ahol a kijárati } \\
\text { csomóponti ágak összesített kapacitása befolyásolja az eredményt, az áthaladási } \\
\text { időveszteség értéke változatlan marad. A hálózaton nagyobb forgalom jelenik } \\
\text { meg, mint a kijárati csomóponti ágak összesített kapacitása. Ez a kapacitáshiány } \\
\text { erősen visszahat a közúti hálózat csatlakozó elemeire. Az eredmény a } \\
\text { vizsgálathoz felhasznált modellezési környezet következménye. } \\
\text { - „E” szolgáltatási szint ott jelenik meg, ahol a kijárati csomóponti ágak összesített } \\
\text { kapacitása nagyobb, mint a hálózaton megjelenő forgalom nagysága adott } \\
\text { nagyságú forgalmi ráterhelés esetén. (I., II., IV., VI. csoport). } \\
\text { - Fh-nál kisebb forgalmi ráterhelés esetén a vizsgált utcahálózati modellekhez } \\
\text { tartozó eredmények közel azonosak (I., II., IV., VI. csoport). } \\
\text { - Amennyiben a kijárati csomópontokban jelentős áthaladási időveszteség alakul } \\
\text { ki, akkor Fh-t jelentősen meghaladó forgalom esetében (kb. 6500 E/h) az } \\
\text { áthaladási időveszteség instabil lesz, hálózaton kialakuló torlódás hossza és } \\
\text { annak megoszlása hatással lesz az eredmények alakulására (I., II., III., IV., V., } \\
\text { VI. csoport). Ez a jelenség a kijárati csomóponti ágak kapacitásával közel } \\
\text { megegyező forgalomnagyságok esetén figyelhető meg. Eredmények hatása a } \\
\text { használt utcaszakaszok aránya és használt utcaszakaszok } \\
\text { kapacitáskihasználtsága forgalmi jellemzőknél is megjelennek, és a forgalom } \\
\text { optimalizált lefolyásának keresésére vezethető vissza. Az s8_1000_8x8 esetben } \\
\text { különösen megfigyelhető, hogy a csomóponti áthaladási időveszteség nagy } \\
\text { forgalmi terhelés következtében hirtelen lecsökken, amikor az utcahálózaton a } \\
\text { torlódás hossza hirtelen megnő. Ezekben az esetekben a csomópont } \\
\text { tehermentesül, hálózaton az időveszteség szétterül, amit az átlagos utazási idő } \\
\text { tendenciájának változatlansága mutat. }\end{array}$ \\
\hline
\end{tabular}




\begin{tabular}{|c|c|}
\hline I. csoport & - \\
\hline II. csoport & - \\
\hline III. csoport & $\begin{array}{l}\text { - Fh-nál kisebb forgalmi ráterhelés esetében a kijárati csomópontok száma minél } \\
\text { kevesebb, annál magasabb a csomóponti áthaladási időveszteség. } \\
\text { - Amennyiben a kijárati csomópontok sarok helyzetűek, úgy az áthaladási } \\
\text { időveszteség Fh-nál nagyobb forgalmi terhelés esetén magasabb, mint élek } \\
\text { mentén csomópontok esetében azonos forgalomnagyság mellett. A kijárati } \\
\text { csomópontok saroki elhelyezkedése esetén egy kijárati csomópontot két irányból } \\
\text { tud elérni a hálózaton megjelenő forgalom, az élek mentén elhelyezkedő kijárati } \\
\text { csomópont estén három irányból képes azokat elérni a hálózaton kialakuló } \\
\text { forgalom. Hálózaton szétterülő forgalom több csomóponti ágról érkezik, így } \\
\text { azonos nagyságú forgalom kisebb áthaladási időveszteséggel tudja a kijárati } \\
\text { csomópontokon keresztül a vizsgált területet elhagyni. }\end{array}$ \\
\hline IV. csoport & - \\
\hline V. csoport & $\begin{array}{l}\text { - Gyűjtőutak és a kijárati csomópontok szimmetrikus elhelyezkedése esetén a } \\
\text { legkedvezőbb a kijárati csomópontokon kialakuló áthaladási időveszteség. } \\
\text { - Az utcahálózatok belsejében áthaladó gyűjtőutak egymással alkotott } \\
\text { csomópontjainak távolságának növelése a terület súlypontjától növeli a kijárati } \\
\text { csomópontokon kialakuló áthaladási időveszteség. }\end{array}$ \\
\hline VI. csoport & - \\
\hline
\end{tabular}

\section{3. ÖsSZEGZÉs}

A közlekedési hálózatok forgalmi kapacitását a forgalom lefolyása szempontjából kritikus elhelyezkedésű (más útvonal használatával nem kikerülhetö) legszükebb keresztmetszet forgalmi kapacitása adja meg. Amennyiben az utcahálózaton a hálózati forgalomlefolyásban betöltött szerepe alapján több, azonos funkciójú, elhelyezkedésủ és a környezetéhez hasonlóan kapcsolódó kritikus elhelyezkedésủ utcahálózati elem található, akkor azok összegzett kapacitása adja meg az utcahálózat forgalmi kapacitását. Ez az érték a vizsgálat során a telítetlen és a túltelített forgalmi állapot határában elhelyezkedő forgalmi határértékként $\left(\mathrm{F}_{\mathrm{h}}\right)$ került meghatározásra. A vizsgált utcahálózatokon ezen értéket követően kezd torlódás kialakulni.

A vizsgált utcahálózati modellek tekintetében az eredmények alapján ilyen kritikus alkotóelemnek tekinthetők a kijárati csomópontok, a kijárati csomóponti ágak elhelyezkedése, azok száma és összegzett forgalmi kapacitása alapján. E két alkotóelem jelentősen befolyásolta a forgalomminőséget jellemző mennyiségek alakulását és a forgalmi határérték $\left(\mathrm{F}_{\mathrm{h}}\right)$ értékét. Mindezek mellett a kijárati csomóponti ágak forgalmi kapacitása szükebb forgalmi keresztmetszetet jelentett. Ezek az utcahálózat forgalmi teljesítményét jobban lehatárolta, mint a kijárati csomópontok kapacitása a vizsgálat során. Amíg $\mathrm{F}_{\mathrm{h}}$-nál alacsonyabb forgalmi ráterhelés esetében a vizsgált forgalomminőségi jellemzők tekintetében kedvezőbb eredményeket adnak az utcahálózatok sarkaiban elhelyezkedő kijárati csomópontok, mert a vizsgált területet kívülről határoló külső gyüjtőutakon nagyobb forgalom jelenik meg. Mindezek mellett

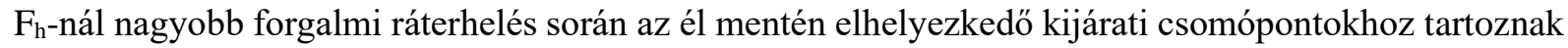
kedvezőbb eredmények. A kijárati csomópontok a belső utcahálózatról több irányból is megközelíthetők, ezáltal a kijárati csomópontokra rávezető utcaszakaszok kisebb nagyságú forgalom jelenik meg.

A vizsgált utcahálózati modellek mérete, alakja és belső utcahálózatának sürúsége az eredményekre kisebb mértékben volt hatással. A topológiai mérőszámok közötti minimális eltérés a vizsgálat eredményeiben kisebb mértékben jelentkezett. A vizsgált területek mérete, alakja, a belső utcahálózat felépítése és sürüsége jellemzően az $\mathrm{F}_{\mathrm{h}}$ - $\mathrm{t}$ meghaladó forgalomnagyságok esetén van hatással az eredményekre. A forgalom utcahálózaton való szétterülése, az érintett utcaszakaszok kapacitáskihasználtsága és a torlódás mértéke mind megjelenik az átlagos utazási idő és az átlagos sebesség alakulásában. Minél nagyobb egy utcahálózat, az átlagos utazási idő értéke $F_{h}$-t meghaladó forgalomnagyságok esetében annál nagyobb. Minél nagyobb az utcahálózat annál kisebb az utcaszakaszok kapacitáskihasználtsága, valamint a használt utcaszakaszok aránya. Ez különösen az egyirányú belső utcaszakaszokból álló utcahálózati modellek esetében, ahol az utcahálózaton közlekedő járművek számára a közlekedésre rendelkezésre álló utcaszakaszok száma jelentősen kevesebb. 
A cikksorozat harmadik részeként a vizsgálati módszertant kiterjesztem valós, lakótelepi utcahálózatok vizsgálatára is. Az elméleti utcahálózatok során megállapított következtetések valós környezetbe kerülnek kiterjesztésre az alkalmazott keretrendszert használva.

\section{IRODALOM}

Akcelik, R. 2003. Speed-flow models for uninterrupted traffic facilities. Akçelik \& Associates Pty Ltd, 1-34.

Háznagy, A., \& Fi, I. 2019. Elméleti utcahálózatok forgalomlebonyolító képességének vizsgálata makroszkopikus modellezési eljárással I. - Kísérleti módszertan. Útügyi Lapok, 7(12), 68-79, https://doi.org/10.36246/UL.2019.1.07

Koller, S. 1986. Forgalomtechnika és közlekedéstervezés. Budapest: Müszaki Könyvkiadó.

Parmenter, D. 2015. Key performance indicators: developing, implementing, and using winning KPIs. John Wiley \& Sons.

PIARC. 2019. Performance Indicators. Retrieved from https://rno-its.piarc.org/en/rno-basics-roaduser-needs-measuring-performance/performance-indicators; Elérve: 2020.03.02.

Transportation Research Board National Research Council. 2010. Highway Capacity Manual "HCM2010." Washington, D.C. 